\title{
ZARZĄDZANIE RYZYKIEM UTRATY NALEŻNOŚCI W PRZEDSIĘBIORSTWACH
}

\begin{abstract}
W opracowaniu przedstawiony został problem zarządzania ryzykiem utraty należności w przedsiębiorstwach. Zaprezentowano istotę należności, przesłanki, w następstwie których one powstają oraz pojawiające się ryzyko wynikające $\mathrm{z}$ odroczonego terminu płatności. Przejawem tego ryzyka jest występowanie należności nieściągalnych lub trudno ściągalnych, które w każdym przypadku negatywnie odbijają się na prowadzonej działalności gospodarczej. Postawy osób decyzyjnych wobec tego typu ryzyka wynikają najczęściej $\mathrm{z}$ cech osobowości, nabytego doświadczenia oraz pełnionych funkcji. Osoby te coraz większą uwagę przywiązują do problematyki zarządzania ryzykiem, które jest traktowane jako zintegrowany system działań zmierzających do kompleksowego zabezpieczenia interesów przedsiębiorstwa. W trakcie prezentowanych rozważań omówiono związek pomiędzy prowadzoną polityką kredytową a posiadaną przez przedsiębiorstwo płynnością finansową, przy czym wskazano, że zbyt wysoka płynność może stanowić zagrożenie. Jednocześnie zwrócono uwagę na konieczność tworzenia i implementacji odpowiednio dopasowanej polityki obrotu należnościami w przedsiębiorstwie przy wykorzystaniu określonych produktów oferowanych m.in. przez banki i ubezpieczycieli. Wśród nich wyróżniono factoring, forfaiting, akredytywę, gwarancje oraz ubezpieczenia należności. Wskazano mechanizmy, w oparciu o które one funkcjonują oraz przesłanki przemawiające za ich wykorzystaniem. W praktycznej części opracowania zaprezentowano strategię zarządzania ryzykiem kredytowym na przykładzie Grupy Kapitałowej KGHM Polska Miedź SA. Jako cel artykułu wskazano analizę i ocenę znaczenia polityki zarządzania należnościami w oparciu o przykład badawczy, który stanowi KGHM Polska Miedź SA.
\end{abstract}

Słowa kluczowe: kredyt kupiecki, ryzyko handlowe, ryzyko polityczne, struktura należności, analiza branżowa

\section{WPROWADZENIE}

Zmiana warunków, w jakich funkcjonują podmioty gospodarcze, w naturalny sposób przekłada się na rozwój ryzyk towarzyszących ich działalności. Coraz częściej ryzyka związane są nie tylko ze zdarzeniami losowymi, ale mogą wynikać z decyzji i działań

\footnotetext{
${ }^{1}$ Dr Robert Dankiewicz (autor korespondencyjny), Zakład Finansów, Bankowości i Rachunkowości, Wydział Zarządzania, Politechnika Rzeszowska, Al. Powstańców Warszawy 8, 35-959 Rzeszów; e-mail: robertdankiewicz@wp.pl

2 Dominik Markusiewicz, Bio Swiss Gen Sp. z o.o.; e-mail: d.markusiewicz@bioswissgen.pl

${ }^{3}$ Katarzyna Tompalska, Podkarpacki Dom Ubezpieczeń Sp. z o.o.; e-mail: katarzyna. Tompalska@vp
} 
niemających charakteru losowego. Bardzo często są to elementy niezależne od działań osób zarządzających, które wywołują niekorzystne zmiany w przepływach finansowych firmy. Dążenie do maksymalizacji zysku wymusiło potrzebę zainteresowania się ,technologią" ryzyka utraty należności, a więc profesjonalnym, planowym i zorganizowanym diagnozowaniem i przeciwdziałaniem stratom powstającym w następstwie jego urzeczywistniania się ${ }^{4}$. Jednostki gospodarcze coraz częściej spotykają się z koniecznością oferowania kontrahentom odroczonego terminu płatności na zobowiązania. Kredyt kupiecki stanowi swego rodzaju lukę finansową pozbawiającą sprzedawcę źródła finansowania, które istniałoby w sytuacji, gdyby sprzedaż i regulacja zobowiązania miały miejsce w tym samym momencie. Dla klientów takie odroczenie terminu płatności stanowi okazję do poprawy własnej płynności finansowej, w przeciwieństwie do kredytodawców, dla których może stanowić zagrożenie objawiające się utratą płynności finansowej ${ }^{5}$.

Celem artykułu jest analiza i ocena znaczenia polityki zarządzania należnościami w oparciu o przykład badawczy, który stanowi KGHM Polska Miedź SA.

\section{ISTOTA ODROCZONYCH TERMINÓW PLATNOŚCI W PRZEDSIĘBIORSTWACH}

W przedsiębiorstwach za główny składnik majątku obrotowego uznawane są należności. Zbyt wysoki ich poziom może prowadzić do kłopotów skutkujących utratą płynności przez firmę. Problem należności nie byłby w ogóle obecny w rzeczywistości gospodarczej, gdyby całość wymiany handlowej była w tym samym momencie dokonywana i opłacana. Realia rynkowe zmuszają sprzedawców do oferowania odroczonych terminów płatności.

Wyróżnia się dwa typy odraczania terminów płatności. Pierwszy z nich manipulacyjny ma na celu pozwolenie nabywcy na dokonanie oceny zgodności dostawy z zamówieniem, a następnie wykonanie przelewu, drugi zaś został zakorzeniony w istniejących zwyczajach handlowych, ponieważ w określonych sektorach gospodarki odroczone terminy płatności są regułą. Odroczone terminy płatności coraz częściej mają postać kredytu kupieckiego udzielanego na okres przekraczający nawet jeden rok. Praktyka udzielania kredytu kupieckiego powoduje znaczący wzrost ryzyka finansowego w prowadzonej działalności gospodarczej. Odległe od siebie momenty sprzedaży oraz zapłaty powodują, że sprzedawcy muszą prowadzić pogłębione analizy dotyczące swoich kontrahentów ${ }^{6}$.

Decyzje podejmowane przez menedżerów znajdują odzwierciedlenie w sytuacji finansowej przedsiębiorstw, dlatego też poszukują oni rozwiązań, które ułatwią im procesy decyzyjne. Sprawdzone narzędzie w tym zakresie stanowi analiza wskaźnikowa?

${ }^{4}$ R. Dankiewicz, Ubezpieczenia $w$ procesie zarzadzania ryzykiem utraty należności [w:] Zarządzanie wartościa instytucji finansowych, red. nauk. R. Płoska, M. Chmielewski, Prace i Materiały Wydziału Zarządzania Uniwersytetu Gdańskiego, Sopot 2011, nr 4/5, s. 256.

5 A. Brzeziński, Kredyt handlowy w małej firmie, ,Zeszyty Naukowe Wyższej Szkoły Bankowej we Wrocławiu" 2014, nr 5(43), s. 27-28.

${ }^{6}$ Z. Dobosiewicz, Wprowadzenie do finansów i bankowości, Warszawa 2007, s. 109-110; D. Seifert, R.W. Seifert, M. Protopappa-Sieke, A review of trade credit literature: Opportunities for research in operations, "European Journal of Operational Research" 2013, Vol. 231, Issue 2, s. 245.

${ }^{7}$ E.F. Brigham, M.C. Ehrhardt, Financial Management: Theory and Practice, South-Western Cengage Learning, 2014, s. 8-10. 
Na rys. 1 zaprezentowano główne przesłanki, które świadczą o posiadaniu lub nieposiadaniu przez jednostkę gospodarczą dostatecznej płynności finansowej.

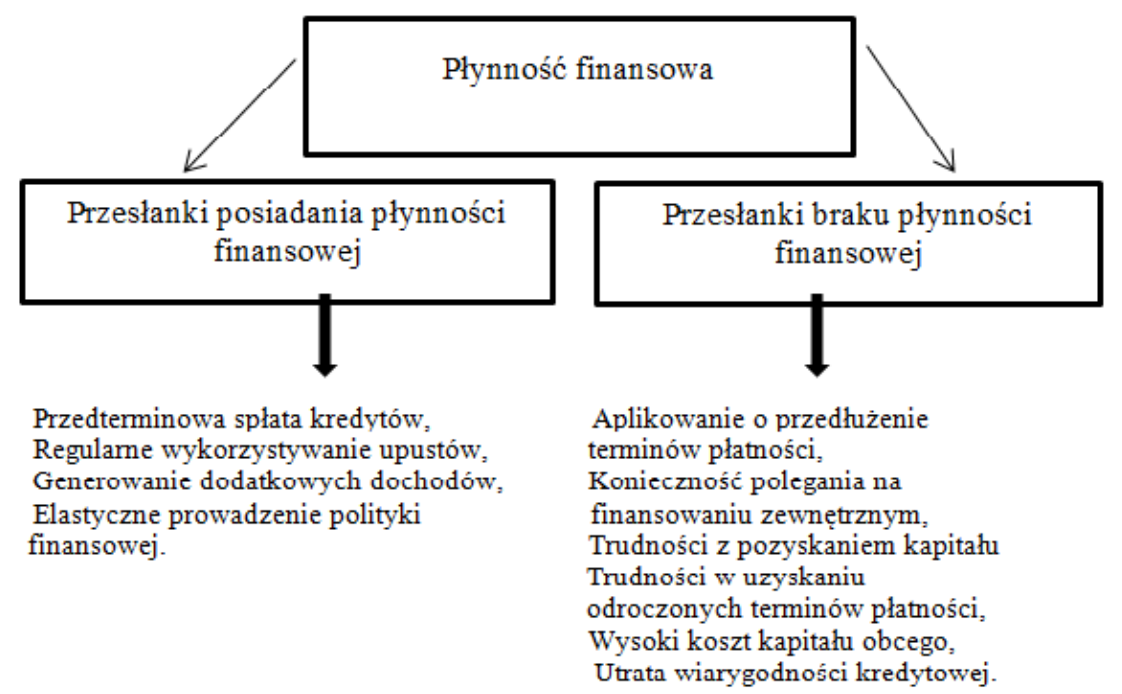

Rys. 1. Oznaki posiadania i braku płynności finansowej przedsiębiorstw

Źródło: opracowanie własne na podstawie: S. Kowalska, Znaczenie płynności finansowej w zarzadzaniu przedsiębiorstwem w sytuacjach kryzysowych, „Zeszyty Naukowe Uniwersytetu Szczecińskiego, Finanse, Rynki Finansowe, Ubezpieczenia”, 2013, nr 58, s. 224.

Informacje na temat należności można pozyskać poprzez dokonanie analizy płynności finansowej jednostki gospodarczej. Pozwala ona na określenie zdolności przedsiębiorstwa do terminowej spłaty zobowiązań. Poprzez przyrównanie płynnych składników majątku (tj. aktywów, które można w szybkim czasie upłynnić) do zobowiązań o krótkim terminie wymagalności można otrzymać kilka wskaźników; do najczęściej wskazywanych należą: wskaźnik płynności finansowej bieżącej, wskaźnik płynności finansowej podwyższonejwskaźnik szybkiej płynności, wskaźnik płynności środków pieniężnych - wskaźnik superszybkiej płynności, wskaźnik określający relację kapitału obrotowego do sumy aktywów. Otrzymane wartości przyrównuje się do planów finansowych jednostki oraz do innych podmiotów gospodarczych z sektora. Zbyt niskie wartości dla wskaźników płynności finansowej są dla firmy źródłem potencjalnych lub już obecnych problemów z wypłacalnością, z kolei zbyt wysokie wartości mogą świadczyć o nadmiernym gromadzeniu środków finansowych lub problemach z rentownościąa .

Jednostki, które regulują swoje zobowiązania po terminie mają znacznie gorszy wizerunek aniżeli te terminowo spłacające zadłużenie. Jeżeli partnerzy biznesowi przedsiębiorstwa mają coraz gorszą opinię na jego temat, to ich wzajemne relacje również się pogarszają. Dla nieterminowo spłacającej swoje długi firmy może to nierzadko oznaczać skrócenie terminów płatności oraz konieczność dodatkowego zabezpieczania transakcji. Instytucje finansowe prowadzą współpracę z podmiotami o pogorszonej płynności finan-

${ }^{8}$ B. Pomykalska, P. Pomykalski, Analiza finansowa przedsiębiorstwa, Warszawa 2007, s. 67-68. 
sowej na zdecydowanie mniej korzystnych warunkach, często dochodzi nawet do sytuacji, że odmawiają im udzielania kredytów lub wypowiadają już istniejące umowy. Kryzys płynności w swej ostatecznej fazie prowadzi do upadłości przedsiębiorstwa ${ }^{9}$.

\section{ZNACZENIE ZARZĄDZANIA NALEŻNOŚCIAMI}

W obecnych realiach gospodarczych rozłączenie momentów sprzedaży i zapłaty jest niezaprzeczalne. Kredyt kupiecki, inaczej zwany handlowym, jest bardzo powszechną praktyką. Kontrahent, któremu został udzielony kredyt kupiecki, sam również dzięki temu jest w stanie oferować go swoim klientom. Ożywia to wymianę gospodarczą i wpływa na wzrost obrotów. Z jednej strony firmy udzielające kredytu kupieckiego odznaczają się wyższym poziomem sprzedaży, $\mathrm{z}$ drugiej zaś są narażone na podwyższone ryzyko braku spłaty należności. Ze wzrostem sprzedaży prowadzonej z odroczonym terminem płatności oraz z ogólnym wydłużaniem się terminów płatności oferowanych kontrahentom rośnie ryzyko pojawienia się problemu należności nieściągalnych lub trudno ściągalnych. Egzekucja tego typu należności wiąże się z dodatkowymi kosztami. Prowadzenie skutecznej polityki kredytowej wobec klientów rodzi konieczność stworzenia w firmie systemu zasad kredytowania i procedur oceny wiarygodności płatniczej kontrahentów.

Można dokonać rozróżnienia trzech podstawowych typów prowadzonej polityki kredytowej: konserwatywna, umiarkowana oraz agresywna. Pierwsza z nich ma na celu niemal całkowitą eliminację odroczonych terminów płatności, druga łączy cechy konserwatywnej oraz agresywnej, nierzadko stosuje się w niej zaliczki, przedpłaty oraz pogłębiony monitoring należności. Strategia agresywna wiąże się dążeniem firmy do maksymalizacji sprzedaży, jej wdrożenie w jednostce podwyższa ryzyko braku spłaty należności przez kontrahentów ${ }^{10}$.

Przedstawiciele przedsiębiorstwa powinni każdorazowo przeprowadzać rachunek opłacalności dotyczący udzielania lub nieudzielania odroczonego terminu płatności określonym kontrahentom, porównując przy tym zyski osiągnięte ze sprzedaży z dodatkowym kosztem należności. Prowadzenie liberalnej polityki kredytowej jest dla przedsiębiorstwa kosztowne. Ponosi ono bowiem koszt należności niepewnych oraz koszt alternatywny kapitału zamrożonego w zwiększonych wskutek liberalnej polityki należnościach. Ostateczne korzyści wynikają z porównania dodatkowego zysku ze stratami związanymi z niepewnymi należnościami i kosztem kapitału zainwestowanego w należnościach. Problem zarządzania ryzykiem należy zatem rozpatrywać w aspekcie efektywności tego procesu, przy uwzględnieniu wyników minimalizacji ryzyka i kosztów poniesionych nakładów na jego minimalizację. Warunkiem skuteczności podjętych działań jest ich pełne zintegrowanie ze wszystkimi procesami zarządzania, co ma prowadzić do pełnego bezpieczeństwa. Świadomość obecności ryzyka i przekonanie o konieczności przeciwdziałania jego skutkom to oczywiście pole indywidualnej decyzji.

\footnotetext{
9 S. Kowalska, Znaczenie płynności finansowej $w$ zarządzaniu przedsiębiorstwem $w$ sytuacjach kryzysowych, „Zeszyty Naukowe Uniwersytetu Szczecińskiego, Finanse, Rynki Finansowe, Ubezpieczenia", 2013, nr 58, s. 224.

${ }^{10}$ A. Wszelaki, Instrumenty usprawniające zarządzanie należnościami z tytułu dostaw i ustug przedsiębiorstwa, „Zeszyty Naukowe Uniwersytetu Szczecińskiego, Finanse, Rynki Finansowe, Ubezpieczenia”, 2012, nr 55, s. 718-722.
} 


\section{NARZĘDZIA WSPOMAGAJĄCE PROCES ZARZĄDZANIA NALEŻNOŚCIAMI}

Proces zarządzania należnościami usprawnia wiele narzędzi mu służących. W literaturze najczęściej wymienia się omówione w dalszej części opracowania faktoring, forfaiting, akredytywę, gwarancje oraz ubezpieczenie należności.

Faktoring polega na sprzedaży przez wierzyciela należności nieprzeterminowanych i niespornych powstałych w efekcie dostawy dóbr i usług, dzięki temu możliwe staje się przyspieszenie przepływu kapitału. W konsekwencji zawarcia umowy faktoringu przeniesione zostają prawa do wierzytelności ze sprzedawcy na ich zbywcę, tj. faktora. Od tej chwili to faktor egzekwuje należność od dłużnika ${ }^{11}$. Schemat faktoringu został przedstawiony na rys. 2 .

Ze względu na sposób zapłaty za należności dokonuje się rozróżnienia na faktoring dyskontowy i zaliczkowy. W pierwszym pierwotny wierzyciel $\mathrm{w}$ momencie podpisania umowy dostaje zapłatę za sprzedane faktury, w faktoringu zaliczkowym faktor płaci zbywcy za wierzytelności albo dopiero w momencie wymagalności faktury albo, gdy dłużnik dokona przedwczesnej spłaty zobowiązań. Z punktu widzenia siedziby kontrahenta wyróżniany jest faktoring krajowy i zagraniczny ${ }^{12}$.

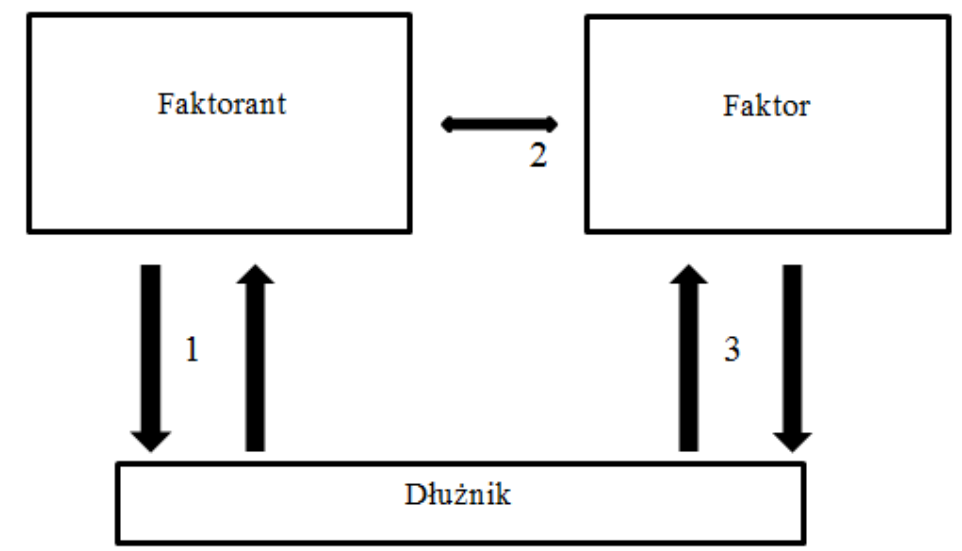

1- Sprzedaż z kredytem kupieckim

2- Umowa faktoringu

3- Spłata wierzytelności

Rys. 2. Schemat faktoringu

Źródło: opracowanie własne na podstawie: D. Czerwińska-Kayzer, A. Bieniasz, Faktoring jako źródto finansowania..., s. 87.

11 W. Janik, A. Paździor, Zarzadzanie finansowe w przedsiębiorstwie, Lublin 2011, s. 169-170.

12 D. Czerwińska-Kayzer, A. Bieniasz, Faktoring jako źródto finansowania dziatalności bieżacej przedsiębiorstwa, ,Zeszyty Naukowe SGGW - Ekonomika i Organizacja Gospodarki Żywnościowej” 2008, nr 66, s. 88. 
Rodzajem zabezpieczenia wierzytelności o konstrukcji podobnej do faktoringu jest forfaiting. Pozwala on na pozyskanie kapitału średnio- i długoterminowego. Forfaiting polega na skupowaniu wierzytelności przed terminem wymagalności, należności takie są najczęściej zabezpieczone wekslem. Cechy charakterystyczne należności objętych forfaitingiem to ich wysokie kwoty, odległe terminy wymagalności oraz zagraniczne pochodzenie kontrahentów. Strony biorące udział w transakcjach forfaitingowych to forfaiter, forfetysta oraz dłużnik forfaitingowy. Funkcję forfaitera najczęściej pełni bank bądź zakład ubezpieczeń; forfetysta to zbywca należności, który dokonuje dostawy dóbr lub usług, zaś dłużnik forfaitingowy jest zobligowany do dokonania zapłaty za fakturę ${ }^{13}$.

Kolejnym rodzajem zabezpieczenia wierzytelności jest akredytywa, zgodnie z którą „bank, działając na zlecenie klienta, ale we własnym imieniu (bank otwierający akredytywę), może zobowiązać się pisemnie wobec osoby trzeciej (beneficjenta), że dokona zapłaty beneficjentowi akredytywy ustalonej kwoty pieniężnej, po spełnieniu przez beneficjenta wszystkich warunków określonych w akredytywie (akredytywa dokumentowa)". Otwarcie akredytywy dokumentowej jest dokonywane na wniosek klienta banku, by zobowiązanie banku wynikające $\mathrm{z}$ akredytywy stało się wymagalne niezbędne jest okazanie określonych w umowie dokumentów, którymi mogą być np. dowody sprzedaży, opłaty celne, listy przewozowe, dokumenty ubezpieczenia a także inne związane i właściwe dla danej transakcji dowody. W chwili spłaty kwoty akredytywy wygasają akredytywa, jak i zobowiązanie jej zleceniodawcy ${ }^{14}$.

Akredytywa ma na celu udzielenie pomocy przez banki reprezentujące importera oraz eksportera $\mathrm{w}$ prowadzeniu międzynarodowej wymiany handlowej. Proces związany z akredytywą dokumentową ma swój początek w momencie sprzedaży, gdy nabywca w swoim banku składa wniosek o przyznanie mu akredytywy, jeżeli bank się zgodzi na jej otwarcie, to następnie przekazuje tę informację do banku sprzedawcy, kiedy nastąpi rejestracja akredytywy w banku eksportera, możliwe staje się dokonanie realnej wymiany handlowej pomiędzy kontrahentami. Realizacja akredytywy następuje poprzez dokonanie zapłaty za towary lub usługi przez dłużnika ${ }^{15}$.

Gwarancje służące zabezpieczeniu utraty należności są udzielane przez banki i zakłady ubezpieczeń. Gwarant na piśmie zobowiązuje się spełnić na rzecz beneficjenta gwarancji określone świadczenie w sytuacji, gdyby jej zleceniodawca nie wywiązał się z niego w terminie oznaczonym w umowie. Beneficjentem w gwarancji jest podmiot zamawiający dobra bądź usługi, zaś zleceniodawcą ich wykonawca ${ }^{16}$. Wystawienie gwarancji nie zwalnia dłużnika z odpowiedzialności za niewykonanie lub niewłaściwe wykonanie zobowiązania. Jeżeli nawet dochodzi do wypłaty z tytułu gwarancji, gwarant może zażądać od dłużnika zwrotu wypłaconych kwot. Dodatkowo wierzyciel może mieć nadal roszczenie do dłużnika, chociażby z tego tytułu, że gwarant pokrył tylko część szkody.

13 D. Muraleedharan, Modern Banking: Theory and Practice, Delhi 2014, s. 151-152.

14 A.M. Olkiewicz, Rola instrumentów bankowych i ubezpieczeniowych $w$ ograniczaniu ryzyka handlowego przedsiębiorstw, „Zeszyty Naukowe. Polityki Europejskie, Finanse i Marketing” 2010, nr 4(53), s. 295.

15 J. Zając, Zastosowanie elektronicznej wymiany danych $w$ procesach trade finance, „Studies \& Proceedings of Polish Association for Knowledge Management” 2010, t. 29, s. 159-160.

16 A. Wąsowski, Rola gwarancji bankowej i ubezpieczeniowej jako zabezpieczenia należytego wykonania umowy w zamówieniach publicznych na roboty budowlane, „Przegląd Prawniczy, Ekonomiczny i Społeczny” 2014, nr 3/2014, s. 184-185. 
Gwarancje ubezpieczeniowe to produkty oferowane przez ubezpieczycieli przyporządkowane do 15 grupy II Działu ubezpieczeń ${ }^{17}$. Ich schemat działania został zaprezentowany na rys. 3 .

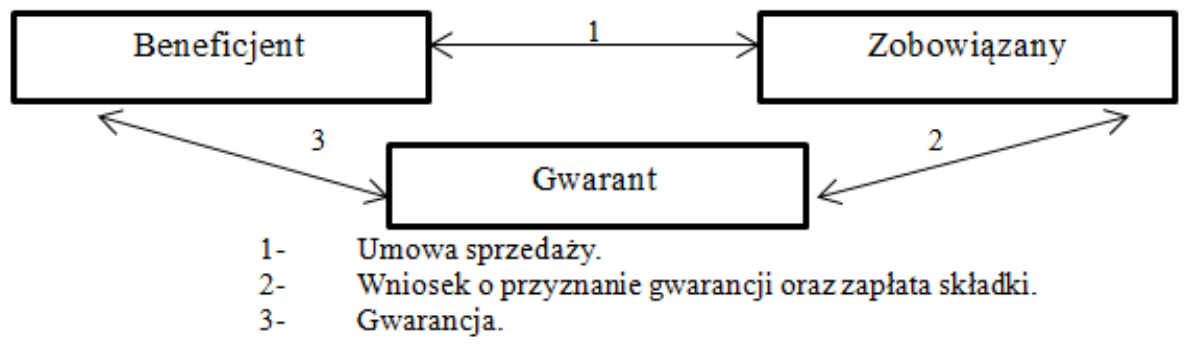

Rys. 3. Mechanizm działania gwarancji ubezpieczeniowej

Źródło: opracowanie własne na podstawie: A. Jańska, Ocena ryzyka w procesie udzielania ubezpieczeniowych gwarancji kontraktowych, „Copernican Journal of Finance \& Accounting” 2013, Vol. 2, Issue 1, s. 94.

Sposobem na redukcję ryzyka braku spłaty należności przez kontrahentów jest ubezpieczenie kredytu kupieckiego, które umieszczone zostało w grupie 14 Działu II $^{18}$.

$\mathrm{Z}$ tego typu transakcją mamy do czynienia, gdy z tytułu łączącego strony stosunku prawnego każda z nich ma spełnić świadczenie na rzecz drugiej, przy czym ustalone terminy spełnienia świadczenia są różne. W efekcie jedna strona stosunku musi wcześniej spełnić świadczenie na rzecz drugiej, a następnie oczekiwać na świadczenie wzajemne drugiej strony. Podmiot, który spełnia swe świadczenie wcześniej, nazywany jest kredytodawcą, natomiast podmiot, którego świadczenie ma być spełnione później - kredytobiorcą. Produkt najczęściej obejmuje:

- ubezpieczenie należności,

- podstawowe informacje o sytuacji kontrahenta, co jest o tyle ważne, że zainteresowani bardzo często nie mają możliwości pozyskania takich informacji, a jeżeli takowe się pojawią, to koszty ich pozyskania mogą być nadmierne,

- prowadzenie w przypadku powstania szkody przez zakład ubezpieczeń postępowania windykacyjnego i regresowego,

- pomoc w kształtowaniu własnej polityki kredytowej.

Ubezpieczenie może być zawierane w zasadzie we wszystkich formach przewidzianych dla umowy ubezpieczenia, czyli ubezpieczane mogą być zarówno transakcje z jednym odbiorcą, jak i transakcje z wieloma odbiorcami. Najczęściej stronami umowy ubezpieczenia są dostawca i zakład ubezpieczeń. W praktyce można jednak spotkać takie umowy, w których to kredytobiorca był ubezpieczającym i ubezpieczał kredytodawcę od swojej niewypłacalności. Ubezpieczający dostawca i zakład ubezpieczeń w oparciu o informacje, którymi dysponują ustalają wspólnie przed zawarciem umowy ubezpieczenia, jaki zakres portfela kredytowego jest przeznaczony do ubezpieczenia. Dla całości

17 Załącznik do ustawy z dnia 11 września 2015 r. o działalności ubezpieczeniowej i reasekuracyjnej (Dz.U. z 2015 r., poz. 1844).

18 (tekst jedn. Dz.U. z 2017 r., poz. 1170 ze zm.). 
portfela kredytowego, jak i każdego przyjętego do ubezpieczenia kontrahenta zakład ubezpieczeń wyznacza tzw. limit kredytowy oraz czas jego obowiązywania. Limit ten jest górną granicą odpowiedzialności ubezpieczyciela. Schemat funkcjonowania ubezpieczenia kredytu kupieckiego został zaprezentowany na rys. 4.

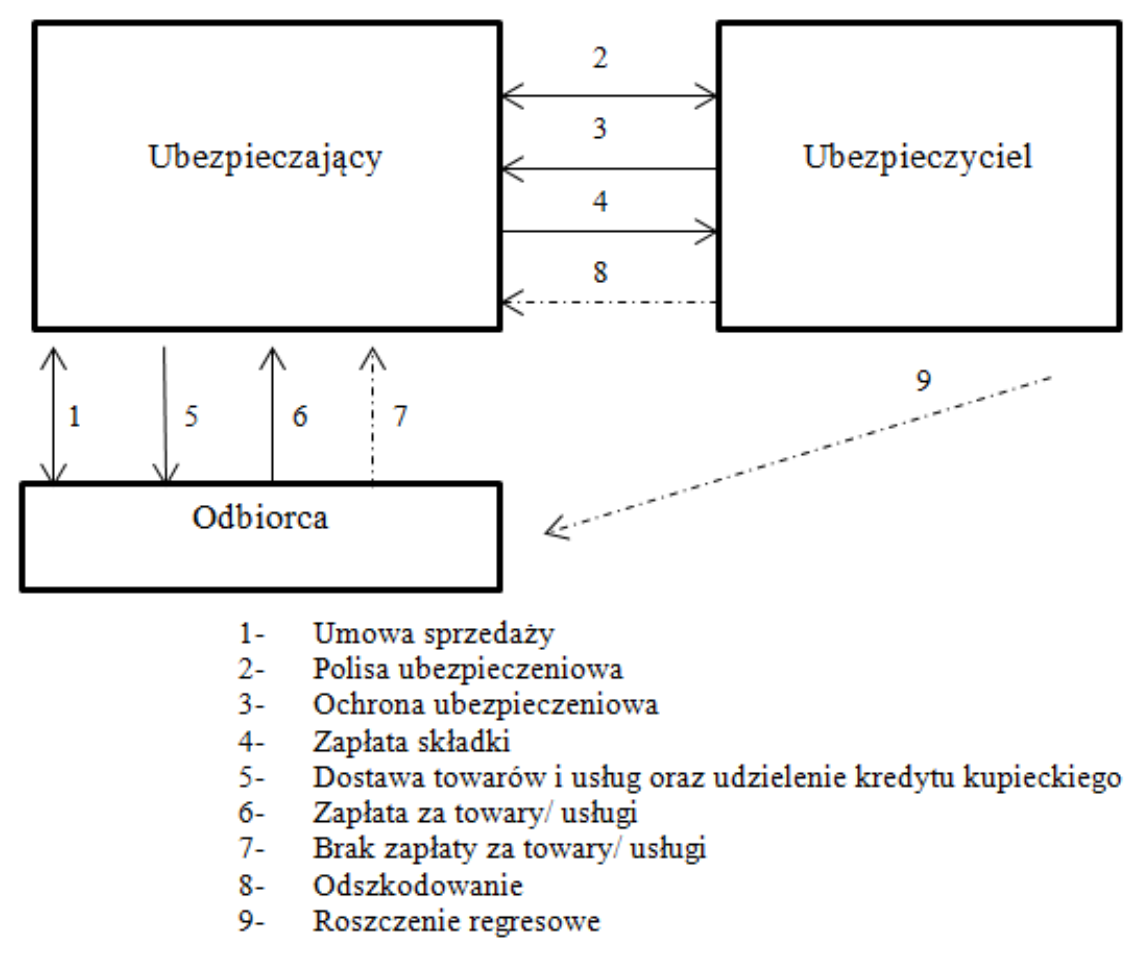

Rys. 4. Schemat działania ubezpieczenia kredytu kupieckiego w przypadku braku zapłaty kontrahenta

Źródło: opracowanie własne na podstawie: A. Becella, Kierunki rozwoju ubezpieczenia kredytu kupieckiego w Polsce, „Studia Oeconomica Posnaniensia” 2015, Vol. 3, No. 2, s. 97.

W ubezpieczeniu kredytu kupieckiego przez szkodę rozumiany jest brak spłaty należności przez kontrahenta. W przypadku nieotrzymania przez dostawcę dóbr lub usług zapłaty za dostarczony towar lub wykonaną usługę może on wnioskować o wypłatę odszkodowania przez zakład ubezpieczeń. Odszkodowanie najczęściej jest wypłacane, gdy:

- zostanie ogłoszona upadłość dłużnika,

- zostanie wszczęte postępowanie układowe z dłużnikiem,

- bezskutecznie zakończy się egzekucja należności z majątku dłużnika,

- nastąpi przewlekła zwłoka dłużnika w zapłacie należności.

W momencie zapłaty odszkodowania na zakład ubezpieczeń przechodzą wszelkie prawa ubezpieczającego wobec klienta. Od tego momentu zakład ubezpieczeń jest upraw- 
niony w ramach roszczenia regresowego do ubiegania się od dłużnika spłaty powstałych zobowiązania $^{19}$.

\section{STRATEGIA ZARZĄDZANIA NALEŻNOŚCIAMI NA PRZYKŁADZIE KGHM POLSKA MIEDŹ SPÓŁKA AKCYJNA}

Grupa Kapitałowa KGHM Polska Miedź SA wdrożyła politykę zarządzania ryzykiem finansowym, które zostało podzielone na trzy główne obszary: ryzyko rynkowe, kredytowe oraz płynności. Przez ryzyko kredytowe rozumiana jest możliwość braku spłaty należności przez kontrahentów. W ramach ryzyka kredytowego dokonany został jego pogłębiony podział na trzy główne obszary związane z wiarygodnością płatniczą klientów, wiarygodnością kredytową instytucji finansowych, z którymi dokonywane są transakcje zabezpieczające oraz instytucji, którym powierza się wolne środki pieniężne, sytuacją finansową pożyczkobiorców ${ }^{20}$. W tabeli 1 został zaprezentowany procentowy udział należności zabezpieczonych w latach 2011-2015.

Tabela 1. Udział procentowy zabezpieczonych należności w latach 2011-2015

\begin{tabular}{|c|c|c|c|c|c|}
\hline & 2015 & 2014 & 2013 & 2012 & 2011 \\
\hline $\begin{array}{c}\text { udział należności } \\
\text { zabezpieczonych w ogóle } \\
\text { należnosci }\end{array}$ & $95,00 \%$ & $95,00 \%$ & $74,00 \%$ & $82,00 \%$ & $82,40 \%$ \\
\hline
\end{tabular}

Źródło: KGHM, Skonsolidowany Raport roczny RS 2015, 2016, KGHM, Skonsolidowany Raport roczny RS 2014, 2015, KGHM, Skonsolidowany Raport roczny RS 2013, 2014, KGHM, Skonsolidowany Raport roczny RS 2012, 2013, KGHM, Skonsolidowany Raport roczny RS 2011, 2012.

Grupa Kapitałowa ma ściśle określony sposób mitygacji ryzyka związanego z niewypłacalnością kontrahentów. Sytuacja finansowa partnerów biznesowych jest na bieżąco monitorowana i oceniana. Przyznawane im limity kredytowe są analizowane i w razie potrzeby dokonuje się ich redukcji. Wewnątrz Grupy Kapitałowej funkcjonuje system monitoringu należności oraz ich terminów wymagalności. W oparciu o dokonywane analizy przyznawany jest kredyt kupiecki, na który mogą liczyć jedynie kontrahenci terminowo spłacający zobowiązania. W końcu 2015 roku należności pochodzące od wiarygodnych i wieloletnich partnerów stanowiły 90\% ogółu wierzytelności. Sprzedaż nowym partnerom biznesowym odbywa się przy zachowaniu szczególnej ostrożności oznaczającej w praktyce stosowanie przedpłat oraz instrumentów finansowych przenoszących ryzyko braku spłaty na instytucje finansowe ${ }^{21}$. W tabeli 2 został zaprezentowany stopień koncentracji należności od siedmiu największych kontrahentów w latach 2011-2015.

Jednostka dominująca przy zabezpieczaniu należności najczęściej korzysta z następujących instrumentów: hipoteki, inkasa dokumentowe, cesje wierzytelności, gwarancje korporacyjne, zastawy rejestrowe, gwarancje bankowe, weksle, akty notarialne, poddanie się egzekucji, zawieranie w umowie sprzedaży zastrzeżenia, że po otrzymaniu od klienta zapłaty prawo własności zostanie na niego przeniesione, umowa ubezpieczenia kredytu

\footnotetext{
19 A. Becella, Kierunki rozwoju ubezpieczenia kredytu kupieckiego w Polsce, „Studia Oeconomica Posnaniensia" 2015, Vol. 3, no. 2, s. 99-100.

${ }^{20}$ KGHM, Ryzyko kredytowe [w:] Skonsolidowany Raport roczny RS 2015, 2016, s. 52.

${ }^{21}$ Tamże, s. 54.
} 
kupieckiego, którą praktykuje się w sytuacji, gdy danemu kontrahentowi oferowany jest odroczony termin płatności oraz kiedy taka transakcja nie jest zabezpieczona w całości lub wcale ${ }^{22}$. W tabeli 3 zaprezentowano geograficzną koncentrację odbiorców KGHM Polska SA.

Tabela 2. Stopień koncentracji należności od siedmiu największych kontrahentów w ogóle należności

\begin{tabular}{|c|c|c|c|c|c|}
\hline & 2015 & 2014 & 2013 & 2012 & 2011 \\
\hline $\begin{array}{c}\text { saldo należności od 7 } \\
\text { największych odbiorców } \\
\text { jako procent ogółu } \\
\text { należności }\end{array}$ & $56,00 \%$ & $60,00 \%$ & $49,00 \%$ & $32,00 \%$ & $42,00 \%$ \\
\hline
\end{tabular}

Źródło: KGHM, Skonsolidowany...

Tabela 3. Koncentracja geograficzna odbiorców KGHM w latach 2011-2015

\begin{tabular}{|c|c|c|c|}
\hline należności od odbiorców & POLSKA & $\begin{array}{c}\text { UNIA } \\
\text { EUROPEJSKA } \\
\text { (bez Polski) }\end{array}$ & $\begin{array}{c}\text { POZOSTALE } \\
\text { KRAJE }\end{array}$ \\
\hline 2015 & $39 \%$ & $10 \%$ & $51 \%$ \\
\hline 2014 & $31 \%$ & $28 \%$ & $41 \%$ \\
\hline 2013 & $15 \%$ & $32 \%$ & $53 \%$ \\
\hline 2012 & $19 \%$ & $53 \%$ & $28 \%$ \\
\hline 2011 & $23 \%$ & $50 \%$ & $27 \%$ \\
\hline
\end{tabular}

Źródło: KGHM, Skonsolidowany...

Dwa największe podmioty wchodzące w skład Grupy Kapitałowej KGHM Polska Miedź SA i KGHM INTERNATIONAL LTD. działają w jednakowej branży, lecz posiadają odmienne portfele asortymentowe, klientów oraz zasięg geograficzny, które sprawiają, że branżowe ryzyko kredytowe znajduje się na poziomie akceptowalnym przez zarządzających grupą. W ocenie menedżerów udział największych kontrahentów na poziomie $56 \%$ ogółu należności nie stanowi dla jednostki zagrożenia, ponieważ stosowany system monitoringu należności i oceny kontrahentów w tym wypadku się sprawdza. Ponadto w ocenie zarządzających zróżnicowanie geograficzne kontrahentów stanowi kolejny atut prowadzonej polityki obrotu należnościami ${ }^{23}$.

\section{ZAKOŃCZENIE}

Realia, w jakich działają jednostki gospodarcze, wymuszają na nich sprzedaż z odroczonym terminem płatności. Kredyt kupiecki bardzo często jest dla klientów atutem, który może stanowić kluczowy czynnik w doborze partnerów biznesowych. Obecnie trudno byłoby sobie wyobrazić, że praktyka kredytu handlowego mogłaby nie istnieć w gospodarce. Problematyczne mogą okazać się konsekwencje nieodpowiednio prowadzonej

22 Tamże, s. 53-54.

23 Tamże, s. 54. 
polityki zarządzania należnościami. Nieostrożnie przyznawany kredyt kupiecki może w konsekwencji doprowadzić do utraty płynności finansowej przedsiębiorstwa, co niekiedy skutkuje nawet upadłością. Istnieje na rynku wiele dostępnych narzędzi zarządzania należnościami, które najczęściej przy pośrednictwie instytucji finansowych minimalizują ryzyko braku spłaty wierzytelności. Przykład KGHM Polska Miedź SA jasno wskazuje, że prawidłowo ukształtowana i konsekwentnie realizowana polityka zarządzania należnościami w przedsiębiorstwie pozwala jednostce oferować odroczone terminy płatności przy jednoczesnym zachowaniu płynności finansowej oraz odpowiedniego poziomu ściągalności należności.

\section{Literatura}

[1] Becella A., Kierunki rozwoju ubezpieczenia kredytu kupieckiego w Polsce, Studia Oeconomica Posnaniensia, 2015, Vol. 3, No. 2.

[2] Brigham E.F., Ehrhardt M.C., Financial Management: Theory and Practice, SouthWestern Cengage Learning, 2014.

[3] Brzeziński A., Kredyt handlowy w małej firmie, Zeszyty Naukowe Wyższej Szkoły Bankowej we Wrocławiu, 2014, nr 5(43).

[4] Czerwińska-Kayzer D., Bieniasz A., Faktoring jako źródło finansowania działalności bieżacej przedsiębiorstwa, Zeszyty Naukowe SGGW - Ekonomika i Organizacja Gospodarki Żywnościowej 2008, nr 66.

[5] Dankiewicz R., Ubezpieczenia w procesie zarządzania ryzykiem utraty należności [w:] Zarzadzanie wartościa instytucji finansowych, red. nauk. R. Płoska, M. Chmielewski, Prace i Materiały Wydziału Zarządzania Uniwersytetu Gdańskiego, 2011, nr 4/5.

[6] Dobosiewicz Z., Wprowadzenie do finansów i bankowości, Wydawnictwo Naukowe PWN, Warszawa 2007.

[7] Jańska A., Ocena ryzyka w procesie udzielania ubezpieczeniowych gwarancji kontraktowych, „Copernican Journal of Finance \& Accounting” 2013, Vol. 2, Issue 1.

[8] KGHM, Skonsolidowane raporty roczne: RS 2011 (2012), 2012 (2013), 2013 (2014), 2014 (2015), 2015 (2016).

[9] Janik W., Paździor A., Zarządzanie finansowe w przedsiębiorstwie, Politechnika Lubelska, Lublin 2011.

[10] Kowalska S., Znaczenie ptynności finansowej w zarzadzaniu przedsiębiorstwem $w$ sytuacjach kryzysowych, ,Zeszyty Naukowe Uniwersytetu Szczecińskiego, Finanse, Rynki Finansowe, Ubezpieczenia” 2013, nr 58.

[11] Muraleedharan D., Modern Banking: Theory and Practice, PHI Learning Private Limited, Delhi 2014.

[12] Olkiewicz A.M., Rola instrumentów bankowych i ubezpieczeniowych $w$ ograniczaniu ryzyka handlowego przedsiębiorstw, „Zeszyty Naukowe. Polityki Europejskie, Finanse i Marketing" 2010, $\mathrm{nr}$ 4(53).

[13] Pomykalska B., Pomykalski P., Analiza finansowa przedsiębiorstwa, Wydawnictwo Naukowe PWN, Warszawa 2007.

[14] Seifert D., Seifert R.W., Protopappa-Sieke M., A review of trade credit literature: Opportunities for research in operations, "European Journal of Operational Research", 2013, Vol. 231, Issue 2.

[15] (tekst jedn. Dz.U. z 2017 r., poz. 1170 ze zm.). 
[16] Wąsowski A., Rola gwarancji bankowej i ubezpieczeniowej jako zabezpieczenia należytego wykonania umowy $w$ zamówieniach publicznych na roboty budowlane, „Przegląd Prawniczy, Ekonomiczny i Społeczny" 2014, nr 3/2014.

[17] Wszelaki A., Instrumenty usprawniajace zarzadzanie należnościami z tytułu dostaw $i$ ustug przedsiębiorstwa, „Zeszyty Naukowe Uniwersytetu Szczecińskiego, Finanse, Rynki Finansowe, Ubezpieczenia" 2012, nr 55.

[18] Zając J., Zastosowanie elektronicznej wymiany danych $w$ procesach trade finance, Studies \& Proceedings of Polish Association for Knowledge Management, 2010, t. 29.

\section{RISK MANAGEMENT OF RECEIVABLES LOSS IN COMPANIES}

In the article the issue of risk management of receivables loss in companies was presented. The essence of receivables and the related with it question of disconnecting from each other of sales and payment were discussed. There were described the rationale and procedure for trade credit. One pointed to the increasing use of deferred payment for receivables and it was presented the relationship between the credit policy and the liquidity owned by the company. It was stated that traders had to possess an appropriate level of liquidity, which indicated that excessive liquidity could also pose a threat. There were described features of economic units with and without sufficient liquidity. The importance of creating and implementing appropriately tailored policies of receivables turnover in companies was discussed. In the later part of this article there were featured receivables management tools. A short characteristics of factoring, forfaiting, letters of credit, guarantees and credit insurance was done, indicating the mechanisms of their action and the way which could enable efficient trade in receivables in the company. In the last part of the paper there was described the strategy of credit risk management in the Capital Groups KGHM Polska Miedź SA. The aim of the article is to analyze and assess the importance of the receivables management policy based on the research example, which is KGHM Polska Miedź SA.

Keywords: merchant credit, trade risk, political risk, receivables structure, sector analysis

DOI: $10.7862 /$ rz.2017.mmr.40

Tekst złożono w redakcji: grudzień 2017 r.

Przyjęto do druku: styczeń 2018 r. 